\title{
Synthesis, characterization, and catalytic properties of the Li-doped $\mathrm{ZnO}$
}

\author{
Damian Kulawik $^{1} \cdot$ Sandra Żarska $^{1} \cdot$ Agnieszka Folentarska $^{1} \cdot$ Volodymyr Pavlyuk $^{1} \cdot$ Wojciech Ciesielski $^{1}$
}

Received: 30 October 2017 / Accepted: 20 June 2018 / Published online: 2 July 2018

(C) The Author(s) 2018

\begin{abstract}
In this study, attention was directed at the interactions between Li-doped $\mathrm{ZnO}$ systems and rye cereal. The interaction of cereal grains and straws with the transition metal ions is of biochemical importance primarily due to the presence of those complexes in biological systems. Metal/cereal chemistry plays a crucial role in the cross-linking of various biomolecules, and formed systems seem to be promising for various applications, such as material for the production of carbonizate and gaseous substances, which allows for the preparation of second generation biofuels. In the study of cereal $/ \mathrm{metal}$ complexes, thermogravimetric measurements were performed in order to explain the influence of $\mathrm{ZnO}$ and $\mathrm{Li}_{2 \mathrm{x}} \mathrm{Zn}_{1-\mathrm{x}} \mathrm{O}$ oxides on the thermal decomposition of rye grains in relation to their application for biofuel production. The possibility of generation of volatile products and carbonizate was considered. The characterization of carbonizate and volatile products was made. The catalytic properties of $\mathrm{Li}_{2 \mathrm{x}} \mathrm{Zn}_{1-\mathrm{x}} \mathrm{O}$ phases in the decomposition of cereal grains were confirmed through thermal analysis. The thermal degradation of rye grains was catalyzed by $\mathrm{Li}$-doped $\mathrm{ZnO}$ systems. Superior degradation to volatile products depended upon both the botanical origin of the cereal and the catalyzing system.
\end{abstract}

Keywords $\mathrm{Li}_{2 \mathrm{x}} \mathrm{Zn}_{1-\mathrm{x}} \mathrm{O}$ oxides $\cdot$ Catalysis $\cdot \mathrm{DSC} \cdot$ Cereal grains $\cdot$ Li-doped $\mathrm{ZnO}$ systems

\section{Introduction}

New catalytic materials that are based on oxides are highly desirable for environmentally friendly processes and the reduction in the cost of production in modern catalysis. In the literature, there is only one work in relation to the catalyst properties of lithium $\mathrm{Li}$-doped $\mathrm{ZnO}$, which was prepared by an impregnation method, followed by calcination, and then used for the preparation of biodiesel [1].

Li-doped $\mathrm{ZnO}$, according to published data, can be prepared by a number of methods. Du et al. [2] prepared $\mathrm{Li}_{0.2} \mathrm{Zn}_{0.8} \mathrm{O}$ by a solid reaction of $\mathrm{ZnO}$ and $\mathrm{Li}_{2} \mathrm{CO}_{3}$ and described the effects of substitutional $\mathrm{Li}$ atoms on the crystal structure and the structural phase transition. As reported by Zhang et al. [3], the intercalation of lithium zinc oxide $\left(\mathrm{Li}_{\mathrm{x}} \mathrm{ZnO}\right)$ was produced through the

Wojciech Ciesielski

wc@ajd.czest.pl

1 Institute of Chemistry, Environment Protection and Biotechnology, Jan Dlugosz University in Czestochowa, Armii Krajowej 13/15 Ave., 42-200 Czestochowa, Poland electrochemical lithium insertion into a $\mathrm{ZnO}$ film electrode, which led to the obtainment of existing hypervalent molecules $\mathrm{LiOZn}$ and $\mathrm{LiOZn}^{+}$. Shet et al. [4] prepared $\mathrm{Li}^{-}$ doping $\mathrm{ZnO}$ nano-powder with the employment of the solution pyro-hydrolysis method and studied the influence of doping on structural characteristics and photocatalytic activity. The activity of these photocatalysts increases with the increase in Li concentration up to 10 mass\% in nanopowder. The Li-doped p-type $\mathrm{ZnO}$ thin films were grown by employing radio frequency magnetron sputtering [5-8]. The Li-, Na-, and K-doped $\mathrm{ZnO}$ nanoparticles were synthesized by the sol-gel method in a gelatin media by Yousefi et al. [9]. The undoped and Li-doped $\mathrm{ZnO}$ crystallizes in the hexagonal symmetry with a wurtzite-like structure type [10]. ZnO doped with powders of $\mathrm{Li}$ and $\mathrm{Ni}$ was used as a transparent conductive oxide thin film and were prepared by the heat treatment of gels obtained from alcoholic $\mathrm{Zn}\left(\mathrm{CH}_{3} \mathrm{COO}\right)_{2} \cdot 2 \mathrm{H}_{2} \mathrm{O}, \mathrm{LiNO}_{3} \cdot{ }_{n} \mathrm{H}_{2} \mathrm{O}$, and $\mathrm{NiSO}_{4-}$ $6 \mathrm{H}_{2} \mathrm{O}$ solutions with $\left(\mathrm{CH}_{3} \mathrm{CH}_{2} \mathrm{OH}\right)_{3} \mathrm{~N}$ as the chelating agent [11].

Recent studies [12-19] have revealed that the starches of various botanical origins coordinate with metal salts to 
form Werner-type complexes with the metal central ions. The structure of the inner coordination spheres of these complexes depends upon cations and anions of the applied salts. However, the coordination capacity of the starches is usually independent of the botanical origin of the starch. Central ions of the complexes essentially control the thermal stability of complexes and the course and rate of decomposition to gaseous products and carbonizate. In several of the cases, the decomposition temperature of the starches can be considerably lowered, indicating a possibility of energy savings on production of carbonizate and/ or syngas for the Fischer-Tropsch synthesis of biofuels [20-24]. Designing crops for the production of biofuel apart from biomass and wood would stimulate agricultural production for non-nutritional purposes. Till now, the utilization of straws, which forms a considerable portion of crops, has not been studied as a source of biofuel. In this article, the catalytic effect of $\mathrm{Li}_{2 \mathrm{x}} \mathrm{Zn}_{1-\mathrm{x}} \mathrm{O}$ systems upon the thermal decomposition of rye $(\mathrm{R})$ grains was recorded.

\section{Experimental}

\section{Synthesis and phase analysis}

For the synthesis of Li-doped $\mathrm{ZnO}$, analytical grade zinc oxide $(\mathrm{ZnO})$ and lithium hydroxide monohydrate $\left(\mathrm{LiOH} \cdot \mathrm{H}_{2} \mathrm{O}\right)$ were used. The nominal purities of all components $>99.9$ mass $\%$. The pure chemical $\mathrm{ZnO}$ and $\mathrm{LiOH} \cdot \mathrm{H}_{2} \mathrm{O}$ were mixed together in the proportion ratio corresponding to the $\mathrm{LiZnO}$ and $\mathrm{Li}_{2} \mathrm{ZnO}_{2}$ stoichiometry, and these selected mixtures were homogenized by mechanical mixing and then pressed into pellets at $20 \mathrm{MPa}$.

Subsequently, the obtained pallets were put in a porcelain crucible and placed in a resistance furnace where the following thermal cycle was applied: (1) heating $\left(10^{\circ} \mathrm{C} \mathrm{min}^{-1}\right)$ up to $T=400{ }^{\circ} \mathrm{C}$; (2) isothermal plateau $(24 \mathrm{~h})$; (3) heating $\left(10^{\circ} \mathrm{C} \mathrm{min}^{-1}\right)$ up to $T=600{ }^{\circ} \mathrm{C}$; (4) isothermal plateau $(24 \mathrm{~h})$; (5) heating $\left(10{ }^{\circ} \mathrm{C} \min ^{-1}\right)$ up to $T=700{ }^{\circ} \mathrm{C}$; (6) isothermal plateau $(1 \mathrm{~h})$; (7) cooling down (about $5{ }^{\circ} \mathrm{C} \mathrm{min}^{-1}$ ) to room temperature.

After sintering, the sample was triturated and dissolved into distilled water in order to remove any impurities and then dried. The obtained material was examined by X-ray powder diffractometer $(\mathrm{Cu}-\mathrm{K} \alpha$ radiation, step mode of scanning) in order to conduct phase analysis.

Synthesized catalysts of LiZnO were subjected to milling until the grain size was proportional to the grain of the binary $\mathrm{ZnO}$ (purchased commercially). According to its characteristics, the grain size was more than $100 \mathrm{~nm}$ and the specific surface is more than $10-20 \mathrm{~m}^{2} \mathrm{~g}^{-1}$. To the same grain size was a milled reagent (rye grains). After that, the catalyst and reactant powders were mixed in different ratios (1: 1, 1:2, and 1:10) and again milled until homogeneity was achieved throughout the mixture, which was then subjected to catalytic studies.

\section{Thermogravimetry (TG), differential thermogravimetry (DTG), and differential scanning calorimetry (DSC)}

The thermal DSC-TG-DTG analysis was carried out with employment of the NETZSCH STA-409 simultaneous thermal analyzer calibrated with standard indium, tin, zinc, and aluminum of $99.99 \%$ purity. Samples of approximately $0.030 \mathrm{~g}$ were heated in corundum crucibles with non-hermetic lids. Corundum was the standard. The heating was performed under static conditions in the air in the range of $25-500{ }^{\circ} \mathrm{C}$ with a temperature rate increase of $5 \mathrm{~K} \mathrm{~min}^{-1}$. They provided $\mathrm{a} \pm 0.5{ }^{\circ} \mathrm{C}$ precision in the reading of temperature.

\section{Scanning electron microscopy (SEM) and estimation of element deposition in grain microareas}

A Nova Nano SEM 200 microscope of up to $2 \mathrm{~nm}$ resolution and 70-500,000 $\times$ magnification, equipped with a field FEG Shottky emitter (FEJ Europe Company), was used. An EDS adapter provided an estimation of the metal deposition in grain microareas.

\section{Quadrupole mass spectrometer Thermostar GSD 300 T Balzers coupled with TGA/SDTA 851e Mettler analyzer}

The thermal analysis was carried out with the help of the TGA/SDTA 851e Mettler analyzer. Samples of approximately $0.030 \mathrm{~g}$ were heated in corundum crucibles. Corundum was the standard. The heating was performed under static conditions in the air in the range of $25-500{ }^{\circ} \mathrm{C}$ with a temperature rate increase of $5 \mathrm{~K} \mathrm{~min}^{-1}$ in air atmosphere. Evolving gases were monitored online with a Balzers ThermoStar GSD $300 \mathrm{~T}$ quadrupole mass spectrometer.

\section{Results and discussion}

\section{Structural characterization}

According to the X-ray powder data, the prepared $\mathrm{LiZnO}$ ternary oxides and the binary $\mathrm{ZnO}$ possess hexagonal wurtzite-like structures (Fig. 1). The process of incorporation of lithium into $\mathrm{ZnO}$ binary oxide and the structure of $\mathrm{Li}_{2 \mathrm{x}} \mathrm{Zn}_{1-\mathrm{x}} \mathrm{O}$ ternary phase were investigated by means of 
(a)

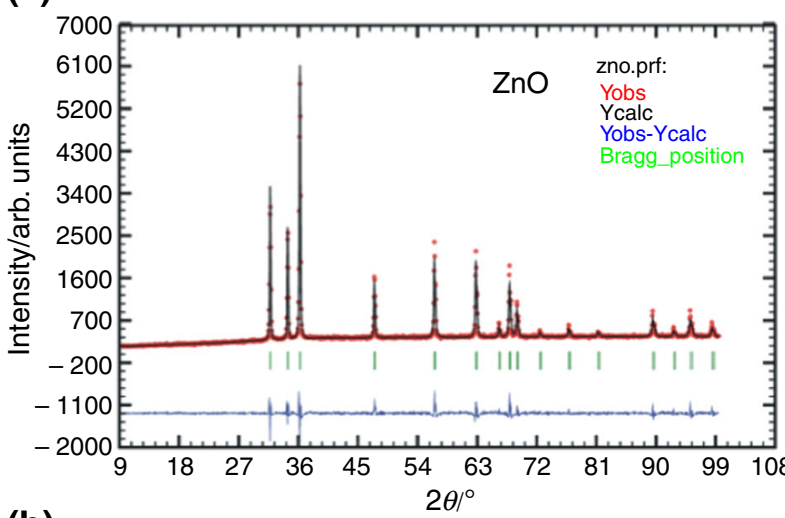

(b)
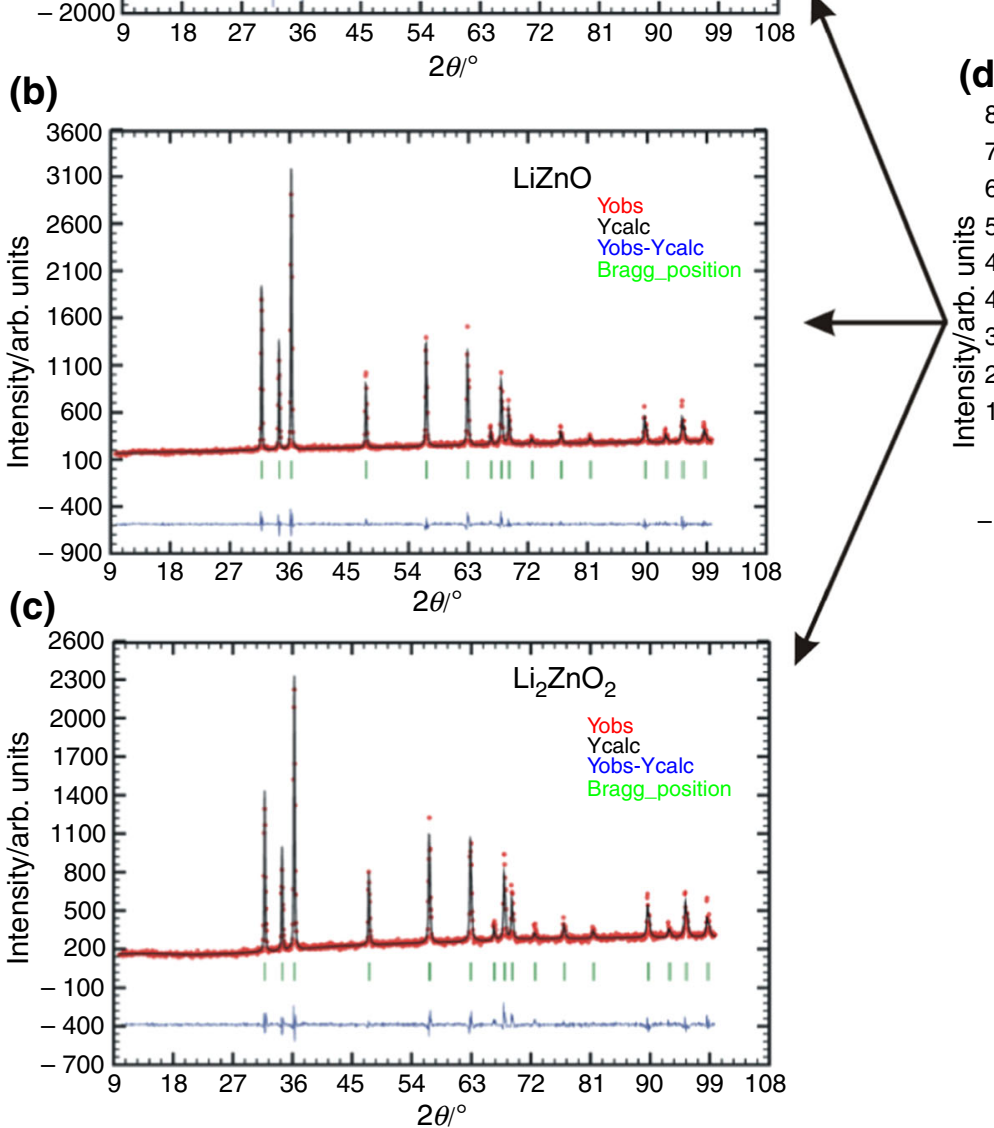

(d)

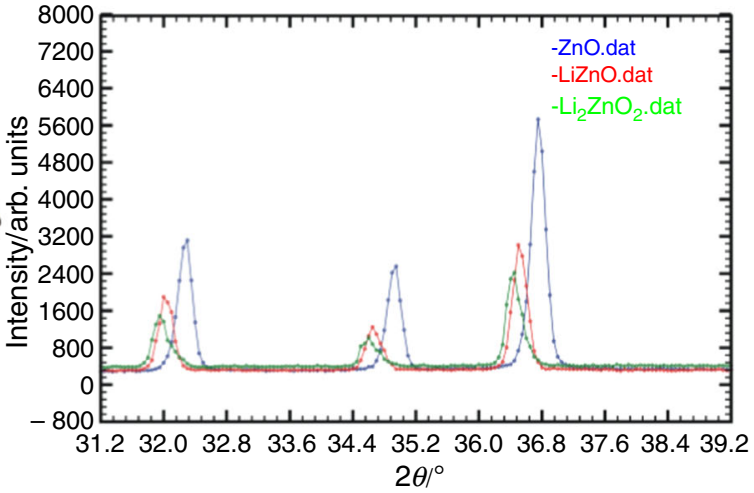

Fig. 1 Powder diffraction patterns for $\mathrm{ZnO}(\mathbf{a}), \mathrm{LiZnO}(\mathbf{b}), \mathrm{Li}_{2} \mathrm{ZnO}_{2}(\mathbf{c})$, and differences between powder patterns (d)

X-ray single-crystal and powder diffractions, differential scanning calorimetry, and thermogravimetry [10]. The formation of $\mathrm{Li}_{2 \mathrm{x}} \mathrm{Zn}_{1-\mathrm{x}} \mathrm{O}$ disordered phase occurs under the action of two simultaneous processes: the first is a partial substitution of zinc atoms by lithium in $2 b$ site $(x=1 / 3, y=2 / 3, z=0.379)$ and the second is an inclusion of an additional lithium atom in $2 a$ site $(x=0, y=0$, $z=0.124)$. The oxygen atoms occupy the $2 b$ site $(x=1 / 2$, $y=2 / 3, z=0)$. The sample of $\mathrm{Li}_{2} \mathrm{ZnO}_{2}\left(\right.$ or $\left.\mathrm{LiZn}_{0.5} \mathrm{O}\right)$ belong to $\mathrm{Li}_{2 \mathrm{x}} \mathrm{Zn}_{1-\mathrm{x}} \mathrm{O}$ disordered phase at $x=0.5$. In the process of intercalation, the lithium atoms provide only one mechanism and leads to $\mathrm{Li}_{\mathrm{x}} \mathrm{ZnO}$ phase composition. The sample with $x=1$ (LiZnO) was also prepared. However, the X-ray data indicated that this phase has the same hexagonal structure as the $\mathrm{Li}_{2 \mathrm{x}} \mathrm{Zn}_{1-\mathrm{x}} \mathrm{O}$. The refined unit cell dimensions are $a=3.2497(1), c=5.2084$ (3) $\AA$ (for $\mathrm{ZnO}$ ), $a=3.2510(1), c=5.2088(2) \AA$ (for $\mathrm{LiZnO}$ ), and $a=3.25372(9), c=5.2127(1) \AA$ (for $\mathrm{Li}_{2} \mathrm{ZnO}_{2}$ ). It should be noted that an increase in the area of unit cell is caused by the increased of lithium content in the hexagonal structure. It also confirms the shift of position of the reflections in the diffraction patterns (Fig. 1d). 


\section{Catalytic properties}

\section{State of preexisting and initial research indicating the feasibility of the research objectives}

The resulted spectrum of the cereal systems with the added potential catalyst was compared to the grain distribution curve (red line) (Fig. 2). Rye grain begins to decompose at about $275{ }^{\circ} \mathrm{C}$, while at $500{ }^{\circ} \mathrm{C}$ about $20 \%$ of carbonizate is obtained. The main distribution peak is observed at $469^{\circ} \mathrm{C}$. The addition of $\mathrm{ZnO}$ 1:1 (mass) (green line), 1:2 (purple line), and 1:10 (blue line) causes an increase in the thermal resistance of the studied systems. This increases in the amount of heat used, disqualifying $\mathrm{ZnO}$ as a potential catalyst.

TG curves indicate that the decomposition temperature is also slightly higher for all the system grains with the $\mathrm{ZnO}$ (Fig. 3). From the viewpoint of mass loss for the cereal grains, $\mathrm{ZnO}-10: 1$ shows a small loss of mass (about 7\%) in relation to the others (about 55-58\%). Decomposition of such systems can be used to obtain large amounts of carbon carbonizate, albeit by using a larger quantity of energy (heating to a temperature of about $25.1{ }^{\circ} \mathrm{C}$ higher than the grain). Decomposition of the other systems is similar to that of the used native cereal (Table 1).

On the basis of the analysis of the spectrum of the TG line, the authors observed an amount of the carbonizate and gaseous products (obtained at $469{ }^{\circ} \mathrm{C}$ ). We found that the addition of $\mathrm{ZnO}$ in any case increases the quantity of resulting carbonizate (Table 2).
It can be concluded that $\mathrm{ZnO}$ does not exhibit catalytic properties in case of thermal decomposition of rye grains.

The DSC curves obtained after the addition of the Li/ $\mathrm{ZnO}(\mathrm{LiZnO})$ systems to the grain as a potential catalyst were compared with the grain decomposition curve (red line) (Fig. 4). LiZnO addition to the grain 1:1 (mass ratio) (green line), 1:2 (purple line) increased the thermal resistance of the resulting systems. The main peak in the decomposition was observed at higher temperatures than that of the cereal grain. This increase in the amount of the heat, caused by the used $\mathrm{LiZnO}$, disqualifies this material as a potential catalyst. However, doping the $\mathrm{LiZnO}$ to the grain in 1:10 (mass ratio) decreased the heat resistance, and the main peak of decomposition was observed at a lower temperature than $26.6{ }^{\circ} \mathrm{C}$ for cereal grains. These results confirm the observations forwarded by Xie et al. [1] for $\mathrm{ZnO}$ systems with added $\mathrm{Li}$ atoms.

The described properties of the tested system allow the possibility of their use as catalysts in the decomposition of biomass (Table 3 ).

The observation of TG lines for grain systems LiZnO displays the highest yield of carbonizate (Fig. 5 and Table 4). For systems (mass ratio) 1:1 and 2:1, the quantity of carbonizate increases slightly in comparison with systems with $\mathrm{ZnO}$. For the 10:1 (cereal grain/LiZnO) compared to the system (cereal grain/ZnO), the carbonization yield is significantly less (about $30 \%$ ).

The addition of $\mathrm{Li} / \mathrm{ZnO}$ with a higher content of lithium $\left(\mathrm{Li}_{2} \mathrm{ZnO}_{2}\right)$ significantly reduces the decomposition temperature of the grain (Fig. 6). This temperature is lower than the temperature of the main peak for the decomposition of grain cereals for the mass ratio 1:1 (green line) of $12.8^{\circ} \mathrm{C}, 2: 1$ (purple line) of $16.2^{\circ} \mathrm{C}$, and for $10: 1$ (blue
Fig. 2 The DSC curves for $\mathrm{ZnO} /$ rye cereal systems in mass ratio 1:1 (green line), 1:2 (purple line), 1:10 (blue line), and rye cereal (red line). (Color figure online)

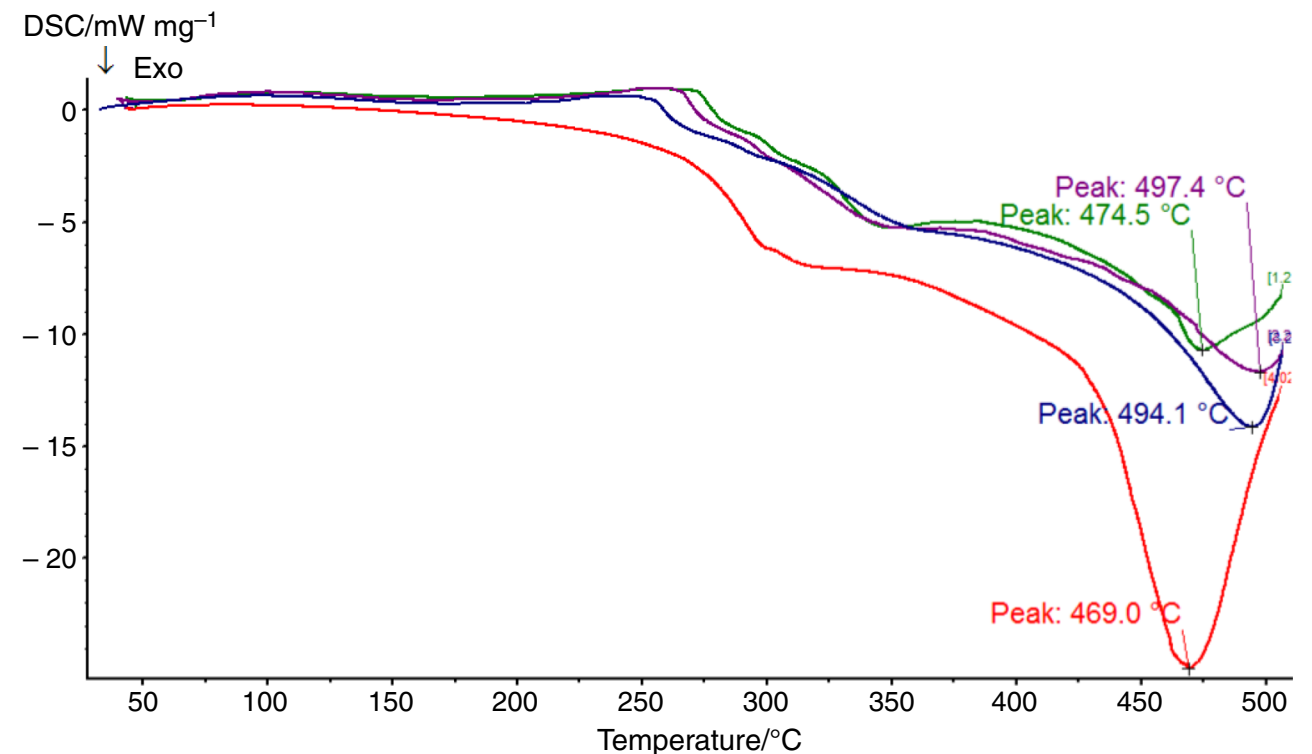




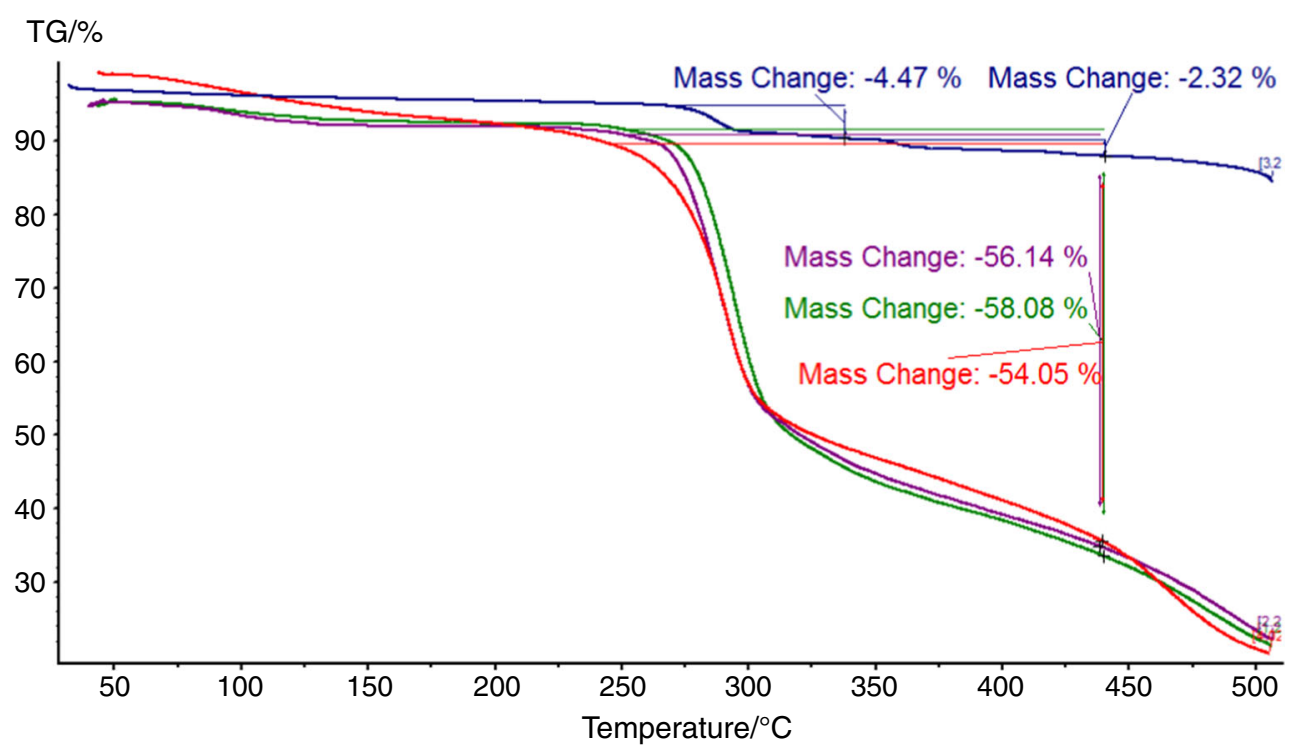

Fig. 3 The TG curves for $\mathrm{ZnO} /$ rye cereal systems in mass ratio 1:1 (green line), 1:2 (purple line), 1:10 (blue line), and rye cereal (red line). (Color figure online)

Table 1 The parameters of thermal analysis for cereal grains and $\mathrm{ZnO}$

\begin{tabular}{llllr}
\hline Sample & Temp. range $/{ }^{\circ} \mathrm{C}$ & TG & \multicolumn{2}{l}{ DSC } \\
\cline { 3 - 5 } & & Mass loss $/ \%$ & Temp. $/{ }^{\circ} \mathrm{C}$ & $\Delta H / \mathrm{J} \mathrm{g}^{-1}$ \\
\hline Rye grains & $250-500$ & 54.05 & 469.0 & +376.3 \\
Rye grains/ZnO 1:1 & $250-500$ & 58.08 & 474.5 & +64.2 \\
Rye grains/ZnO 2:1 & $250-500$ & 56.14 & 497.4 & +50.7 \\
Rye grains/ZnO 10:1 & $250-500$ & 6.79 & 494.1 & +139.8 \\
\hline
\end{tabular}

Table 2 Quantity of carbonizate after deducting the oxide [\% w] at $469{ }^{\circ} \mathrm{C}$ formed by the thermal decomposition of rye grains and volatile products formed after the addition of $\mathrm{ZnO}$

\begin{tabular}{lll}
\hline Sample & Quantity of carbonizate after deducting the oxide/\% & Volatile products/\% \\
\hline Rye grains & 34.50 & 54.05 \\
Rye grains/ZnO 1:1 & 21.56 & 58.08 \\
Rye grains/ZnO 2:1 & 22.53 & 56.14 \\
Rye grains/ZnO 10:1 & 85.34 & 6.79 \\
\hline
\end{tabular}

line) at $31.5^{\circ} \mathrm{C}$. The analysis indicates that the addition of the "catalyst" 10:1 compared appropriately to cereals in terms of energy decomposition of cereal grains.

On the basis of a comparison of thermal effects, it can be concluded that the addition of the "catalyst $\mathrm{LiZnO}$ and $\mathrm{Li}_{2} \mathrm{ZnO}_{2}$ " reduced caloric capacity. The used $\mathrm{Li}_{2 \mathrm{x}} \mathrm{Zn}_{1-\mathrm{x}} \mathrm{O}$ systems reduce the amount of heat discharged into the environment. This process of reducing the consumption of water is used for cooling systems and also reducing the thermal pollution of the water. Research shows that the best catalytic effect is from used systems: $\mathrm{LiZnO}, \mathrm{Li}_{2} \mathrm{ZnO}_{2}$, and $\mathrm{ZnO}$ have $\mathrm{Li}_{2} \mathrm{ZnO}_{2}$. The addition of $\mathrm{Li}_{2} \mathrm{ZnO}_{2}$, in comparison with other investigated systems, reduces the amount of heat discharged into the environment (Tables 5, $6)$.

TG analysis indicates a better performance of carbonizate after the addition of the systems "catalyst $\mathrm{Li}_{2-}$ $\mathrm{ZnO}_{2}$ " to the grain at 1:2 and 1:10 (Fig. 7).

In [10], it is seen that the size of the unit cell of $\mathrm{ZnO}$ and $\mathrm{Li} / \mathrm{ZnO}$ structures increases in the order: $\mathrm{ZnO} \rightarrow \mathrm{LiZnO} \rightarrow \mathrm{Li}_{2} \mathrm{ZnO}_{2} \cdot \mathrm{Li}^{+}$ions are present outside the cells, and their number is the highest in the case of $\mathrm{Li}_{2} \mathrm{ZnO}_{2}$. Current research has shown that $\mathrm{Li}^{+}$ions have an effect on the amount of carbonizate. The increase in $\mathrm{Li}^{+}$ 


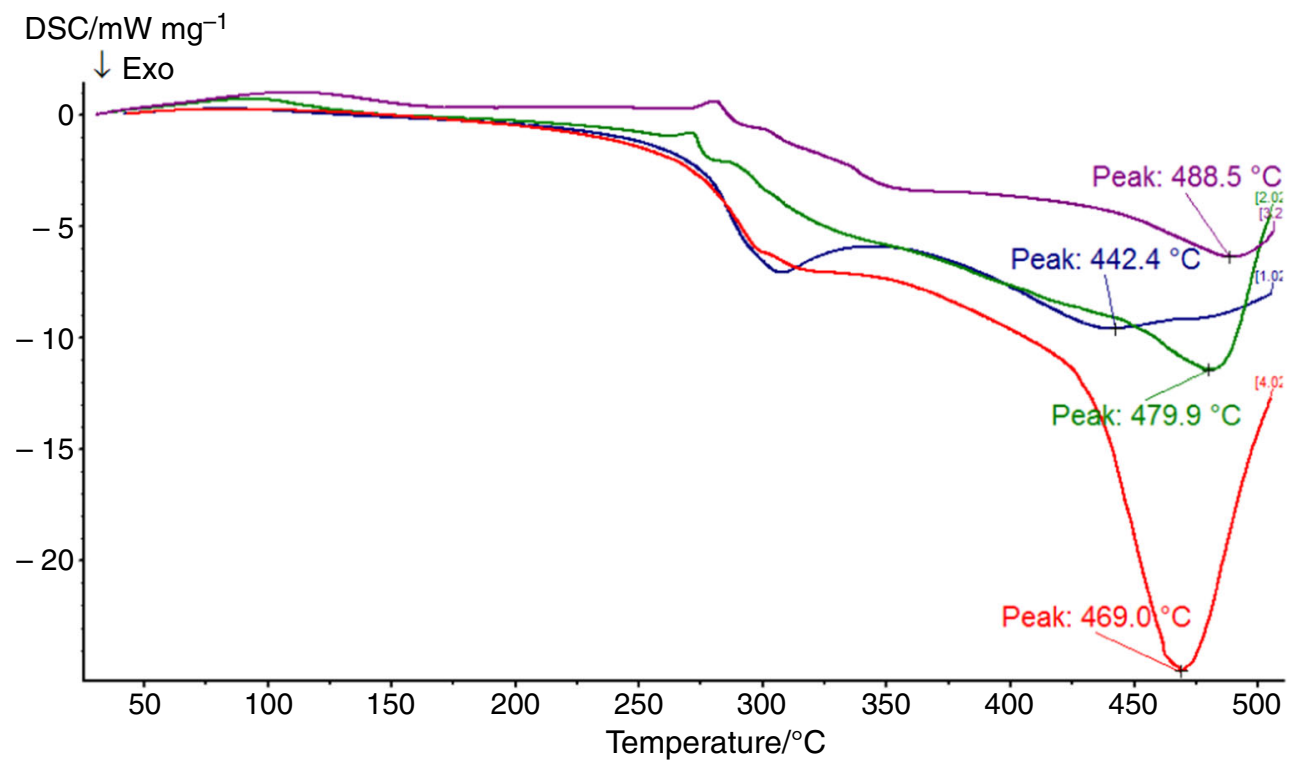

Fig. 4 The DSC curves for LiZnO/rye cereal systems in mass ratio 1:1 (green line), 1:2 (purple line), 1:10 (blue line), and rye cereal (red line). (Color figure online)

Table 3 The parameters of thermal analysis for cereal grains and $\mathrm{LiZnO}$

Fig. 5 The TG curves for $\mathrm{LiZnO/rye} \mathrm{cereal} \mathrm{systems} \mathrm{in}$ mass ratio 1:1 (green line), 1:2 (purple line), 1:10 (blue line), and rye cereal (red line). (Color figure online)

\begin{tabular}{llllr}
\hline Sample & Temp. range $/{ }^{\circ} \mathrm{C}$ & TG & \multicolumn{2}{l}{ DSC } \\
\cline { 3 - 5 } & & Mass loss $/ \%$ & Temp. $/{ }^{\circ} \mathrm{C}$ & $\Delta H / \mathrm{J} \mathrm{g}^{-1}$ \\
\hline Rye grains & $250-500$ & 54.05 & 469.0 & +376.3 \\
Rye grains/LiZnO 1:1 & $250-500$ & 56.03 & 479.9 & +69.2 \\
Rye grains/LiZnO 2:1 & $250-500$ & 57.28 & 488.5 & +31.5 \\
Rye grains/LiZnO 10:1 & $250-500$ & 41.82 & 442.4 & +19.9 \\
\hline
\end{tabular}

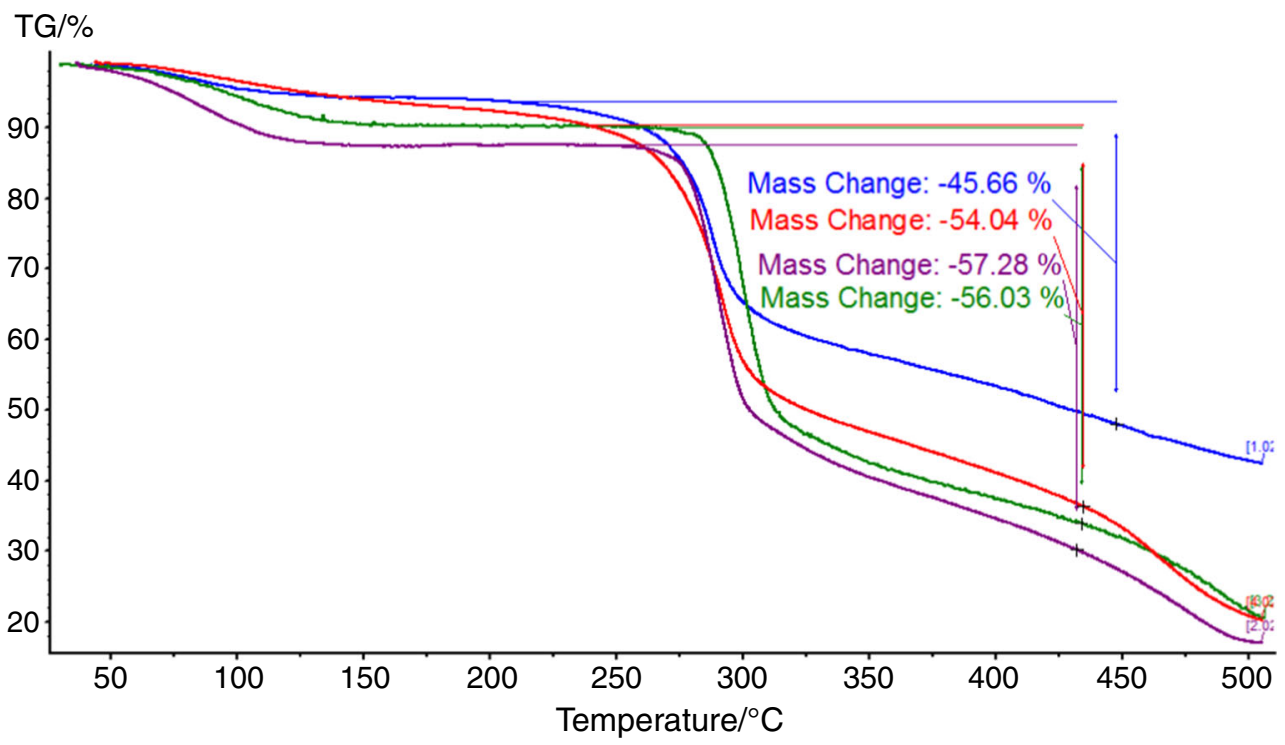

ions influences the reduction of mass of carbonizate and increase in the volume of volatile products.

After decomposition of cereals, the structure of catalyst material does not change in the presence of $\mathrm{Li}_{2 \mathrm{x}} \mathrm{Zn}_{1-\mathrm{x}} \mathrm{O}$
(Fig. 8). Lowering the temperature distribution of grain and no change in the structure of $\mathrm{Li} / \mathrm{Zn} / \mathrm{O}$ systems reveals the catalytic properties of these oxides. 
Table 4 Quantity of carbonizate after deducting the oxide $\left[\% \mathrm{w}\right.$ ] at $500{ }^{\circ} \mathrm{C}$ formed by thermal decomposition of rye grains and volatile products formed after the addition of $\mathrm{LiZnO}$

\begin{tabular}{lll}
\hline Sample & Quantity of carbonizate after deducting the oxide/\% & Volatile products/\% \\
\hline Rye grains & 34.50 & 54.05 \\
Rye grains/LiZnO 1:1 & 23.20 & 56.03 \\
Rye grains/LiZnO 2:1 & 29.69 & 57.28 \\
Rye grains/LiZnO 10:1 & 54.01 & 41.82 \\
\hline
\end{tabular}

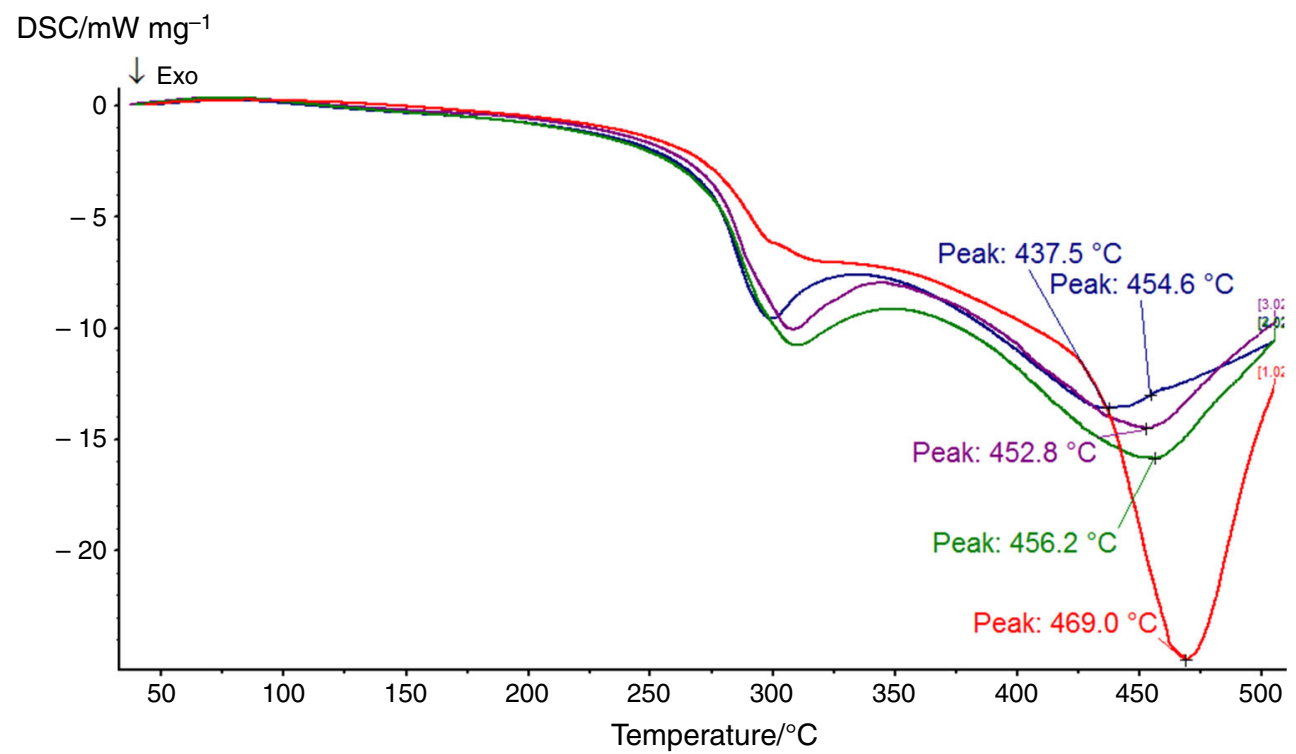

Fig. 6 The DSC Curves for $\mathrm{Li}_{2} \mathrm{ZnO}_{2}$ /rye cereal systems in mass ratio 1:1 (green line), 1:2 (purple line), 1:10 (blue line), and rye cereal (red line). (Color figure online)

Table 5 The parameters of thermal analysis for cereal grains and $\mathrm{Li}_{2} \mathrm{ZnO}_{2}$

Table 6 Quantity of carbonizate after deducting the oxide $[\% \mathrm{w}]$ at $500{ }^{\circ} \mathrm{C}$ formed by thermal decomposition of rye grains and volatile products formed after the addition of $\mathrm{Li}_{2} \mathrm{ZnO}_{2}$

\begin{tabular}{llllr}
\hline Sample & Temp. range $/{ }^{\circ} \mathrm{C}$ & TG & \multicolumn{2}{l}{ DSC } \\
\cline { 3 - 5 } & & Mass loss $/ \%$ & Temp. $/{ }^{\circ} \mathrm{C}$ & $\Delta H / \mathrm{J} \mathrm{g}^{-1}$ \\
\hline Rye grains & $250-500$ & 54.05 & 469.0 & +376.3 \\
Rye grains $/ \mathrm{Li}_{2} \mathrm{ZnO}_{2} 1: 1$ & $250-500$ & 55.75 & 456.2 & +72.3 \\
Rye grains $/ \mathrm{Li}_{2} \mathrm{ZnO}_{2} 2: 1$ & $250-500$ & 49.27 & 452.8 & +35.7 \\
Rye grains $/ \mathrm{Li}_{2} \mathrm{ZnO}_{2}$ 10:1 & $250-500$ & 57.64 & 437.5 & +18.9 \\
\hline
\end{tabular}

\begin{tabular}{lll}
\hline Sample & Quantity of carbonizate after deducting the oxide/\% & Volatile products/\% \\
\hline Rye grains & 34.50 & 54.05 \\
Rye grains $/ \mathrm{Li}_{2} \mathrm{ZnO}_{2} 1: 1$ & 23.63 & 55.75 \\
Rye grains $/ \mathrm{Li}_{2} \mathrm{ZnO}_{2} 2: 1$ & 35.32 & 49.27 \\
Rye grains $/ \mathrm{Li}_{2} \mathrm{ZnO}_{2} \quad 10: 1$ & 40.01 & 55.75 \\
\hline
\end{tabular}

\section{Characterization of carbonizate}

The carbonizate scanning electron microscopy (SEM) photos reveal starch granules (Fig. 9). The SEM shows a large amount of damaged starch granules. Destruction is mainly caused by the oxidation of amylose and amylopectin at the high temperature. There are many cavities visible on the structure of the starch granules. Carbonizates have expanded surface area. The carbonizate structure has numerous defects such as pores and holes. Rye carbonizates can be compared to the structure of the "sponge". The carbonizates have a structure similar to that of a honeycomb. Figure 9 also presents the microspheres obtained by thermal decomposition of starch granules. The 
Fig. 7 TG Curves for $\mathrm{Li}_{2} \mathrm{ZnO}_{2}$ / rye cereal systems in mass ratio 1:1 (green line), 1:2 (purple line), 1:10 (blue line), and rye cereal (red line). (Color figure online)

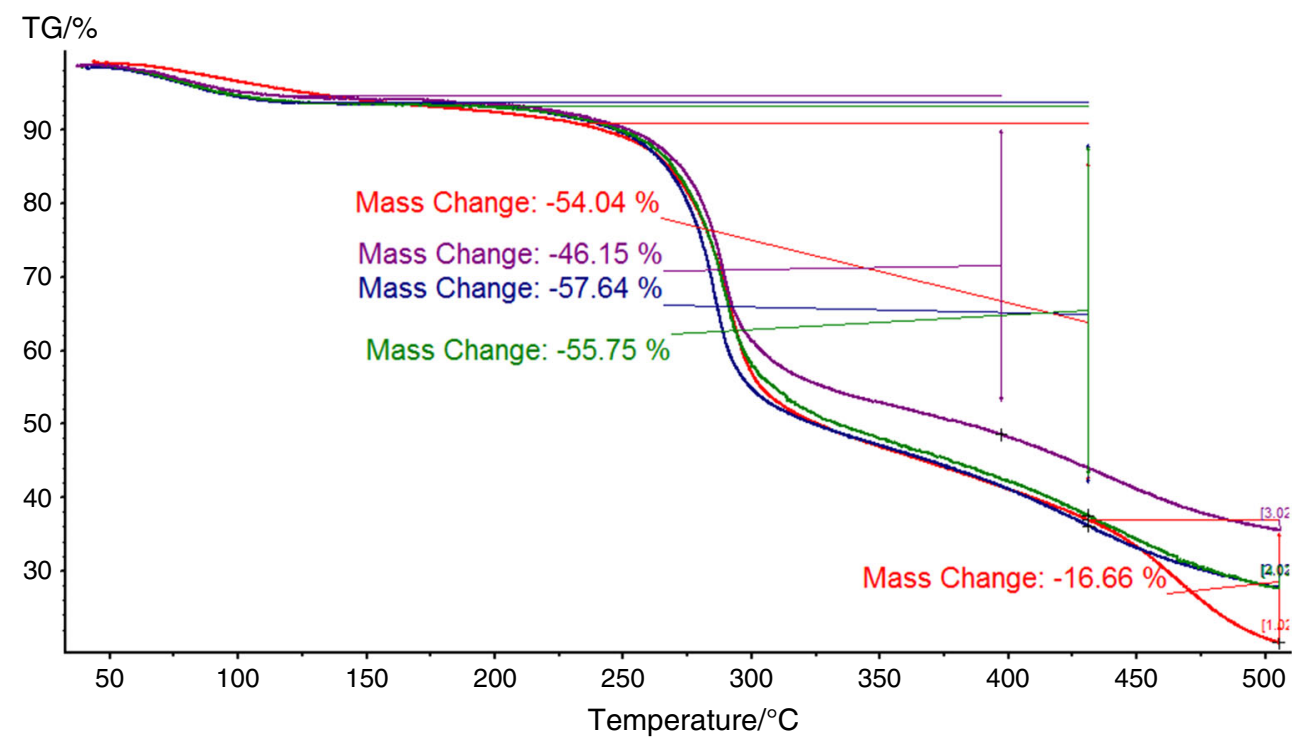

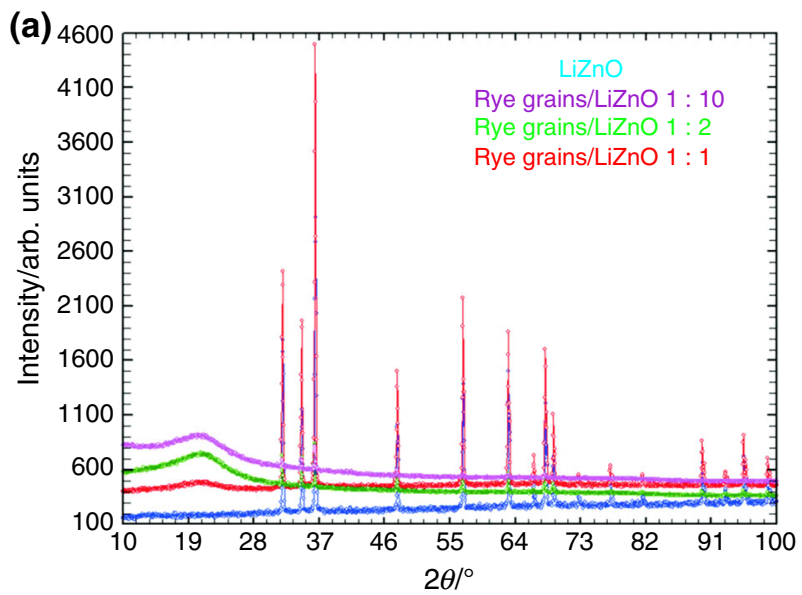

(b)

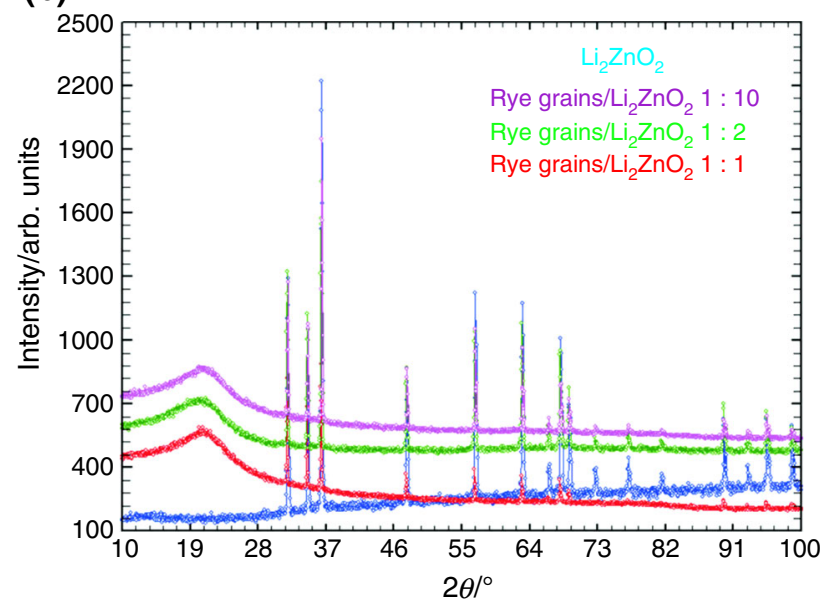

Fig. 8 Powder diffraction patterns for $\mathrm{LiZnO}$ (a) and $\mathrm{Li}_{2} \mathrm{ZnO}_{2}$ (b) after decomposition of cereal grains/catalyst systems

analysis of element concentration on the grain surface, using the method of chemical analysis of microregions
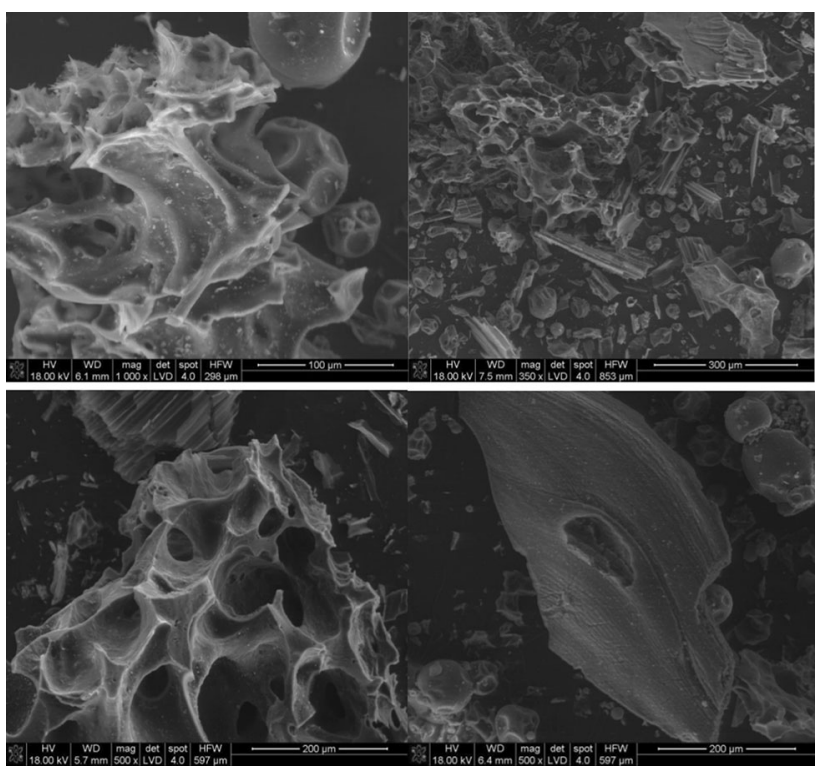

Fig. 9 The surface SEM micrographs of the carbonizate obtained by the decomposition of rye grains

(EDS), reveals that the carbonization process produces a large amount of carbon (Fig. 10). On the surface of the carbonizate, phosphorus compounds such as potassium and magnesium phosphates are observed. An EDS chemical analysis of the surface of the carbonizate shows $\mathrm{Mg}, \mathrm{P}$, and $\mathrm{K}$ elements. The presence of not thermally decomposed phosphates is due to the high decomposition temperature of these compounds. The carbonizate surface is expanded. It indicates the potential use of carbonizate as absorbent and adsorber in various industries. The analyzed carbonizates contain a large amount of nitrogen. This is due to the presence of polysaccharides and proteins in rye grains. 


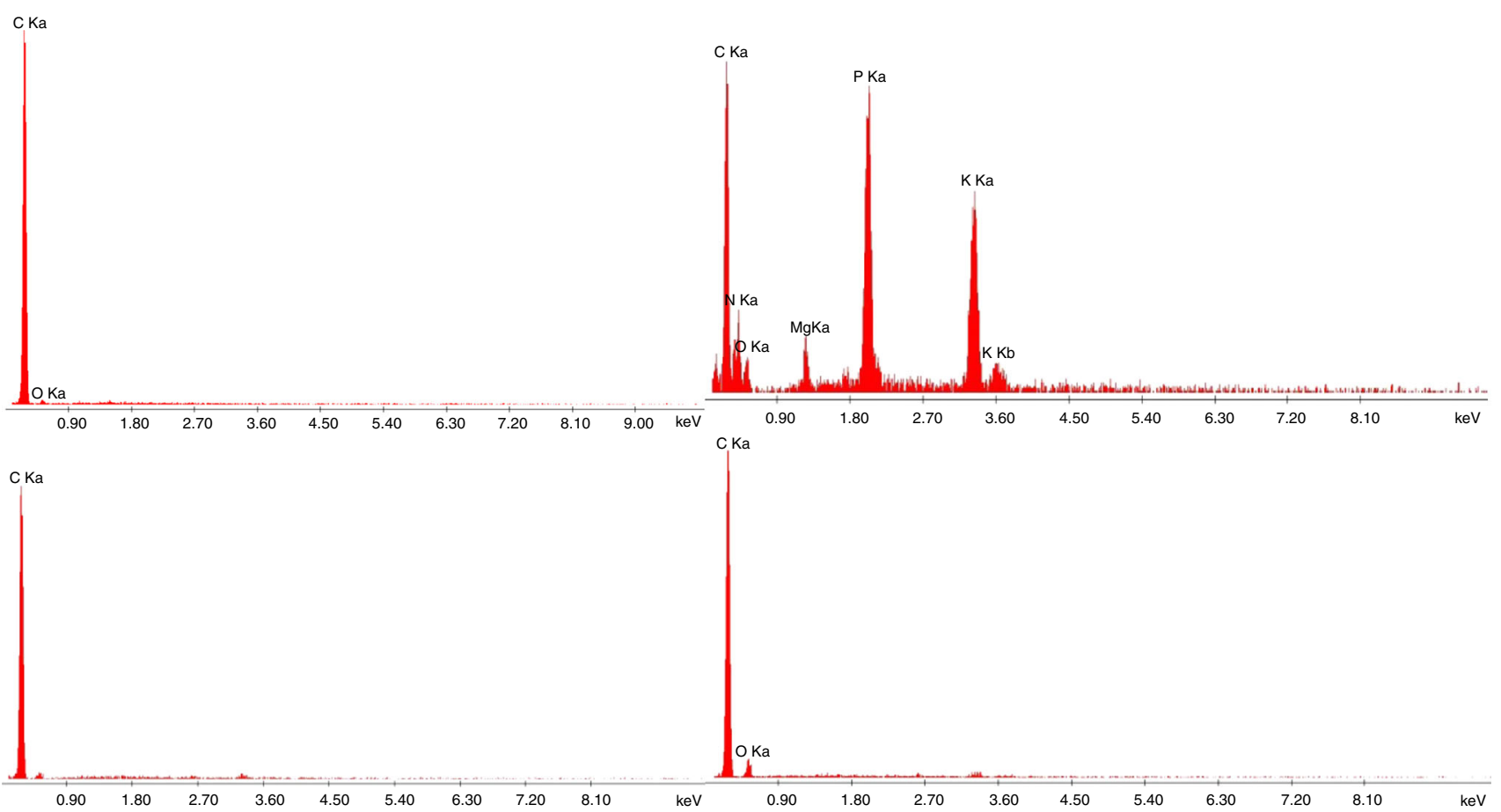

Fig. 10 An EDS spectra of the surface of the carbonizate obtained by the decomposition of rye grains (average deposition of elements in carbonizate on surface SEM micrographs-Fig. 9)

These properties of carbonizate provide an opportunity for their more specific use.

\section{Characterization of volatile products}

In these investigations, as a first experiment, the thermolysis of cereal grains was studied (Table 7).
The decomposition of cereal grain systems affords gaseous products that contain $\mathrm{CO}$, methane, alkenes, and $\mathrm{CO}_{2}$. The carbon monoxide evolving began from ca $250{ }^{\circ} \mathrm{C}$, it reached the maximum yield (35-40\% of the total volatile fraction) at around $350{ }^{\circ} \mathrm{C}$, and its amount declined to $20-25 \%$ at $500{ }^{\circ} \mathrm{C}$. The appearance of $\mathrm{CO}_{2}$ as the sole gaseous product of cereal degradation was already observed at $200{ }^{\circ} \mathrm{C}$ and was at the same level up to $500{ }^{\circ} \mathrm{C}$.

Table 7 Composition of the volatile fraction from the thermal degradation of rye cereal grains in $\mathrm{Li} / \mathrm{ZnO}$ systems presence

\begin{tabular}{|c|c|c|c|}
\hline Temperature range & Rye cereals $/ \%$ & Rye cereals/LiZnO/\% & Rye cereals $/ \mathrm{Li}_{2} \mathrm{ZnO}_{2} / \%$ \\
\hline $500-475$ & CO (25-30), methane (40-45) & $\mathrm{CO}(20-25)$, methane $(25-35)$ & \\
\hline $475-450$ & & & CO (20), methane (25-35) \\
\hline $450-425$ & CO (20-25), methane (40-45) & & \\
\hline $425-400$ & & $\mathrm{CO}(25-30)$, methane (25-35) & \\
\hline $400-375$ & & & Methane (35), CO (25) \\
\hline $375-350$ & Alkenes (1-1.5) & Alkenes (1-1.5) & Alkenes (1-1.5) \\
\hline $350-325$ & Methane (10-15), CO (30-35) & & \\
\hline $325-300$ & & $\mathrm{CO}(30-35)$ & \\
\hline $300-275$ & & & $\mathrm{CO}(30-35)$ \\
\hline \multicolumn{4}{|l|}{$275-250$} \\
\hline $250-225$ & Methane (2), CO (15-20) & Methane (2), CO (20-25) & Methane (2), CO (20-25) \\
\hline $225-200$ & Alkenes & Alkenes & Alkenes \\
\hline $200-175$ & $\mathrm{CO}(5), \mathrm{CO}_{2}(5)$, Tarry products & $\mathrm{CO}(5), \mathrm{CO}_{2}(5)$, Tarry products & $\mathrm{CO}(5), \mathrm{CO}_{2}(5)$, Tarry products \\
\hline $175-150$ & Water & Water & Water \\
\hline
\end{tabular}


Methane appears in the volatile fraction already at $250{ }^{\circ} \mathrm{C}$, but at $1 \%$ yield only. This amount increases to $40-50 \%$ at $450{ }^{\circ} \mathrm{C}$ and then declines to $25-40 \%$ at $500{ }^{\circ} \mathrm{C}$. At $250{ }^{\circ} \mathrm{C}$, alkenes form in the $1-1.5 \%$ amount, and their yield reaches a maximum at around $375{ }^{\circ} \mathrm{C}$. Acetic acid, aldehydes, ketones, and tars constitute a minor fraction of organics. At elevated temperatures, tars undergo degradation to products of a lower molecular weight. Adding catalyst $\mathrm{Li} / \mathrm{ZnO}$ to cereal grains changes the amount of volatile products and the percentage of gas fractions.

\section{Mechanism of catalytic action}

In general, the rye contains polysaccharides up to 70 mass \% starch and up to 17 mass\% dietary fiber (cellulose) and other small amounts of other components including protein, fat, and so on. Polysaccharides, meanwhile, have a general formula of $\mathrm{C}_{x}\left(\mathrm{H}_{2} \mathrm{O}\right)_{y}\left(\right.$ or $\left.\mathrm{C}_{\mathrm{x}} \mathrm{H}_{2 \mathrm{y}} \mathrm{O}_{\mathrm{y}}\right)$, where $x$ is usually a large number between 200 and 2500. During the carbonization of polysaccharides, their decomposition occurs with the separation of carbon, carbon oxides, methane, alkenes, and water molecules:

$\mathrm{C}_{\mathrm{x}} \mathrm{H}_{2 \mathrm{y}} \mathrm{O}_{\mathrm{y}} \rightarrow \mathrm{C}+\mathrm{CO}+\mathrm{CO}_{2}+\mathrm{H}_{2} \mathrm{O}+\mathrm{C}_{\mathrm{n}} \mathrm{H}_{2 \mathrm{n}}+\cdots$

In order for the reaction to take place, the reagent particles must contain sufficient energy to cross the potential energy barrier (activation energy). Like all catalysts, phase $\mathrm{LiZnO}$ forms a transition state (activated complex) with the reactants and reduces free energy in a non-catalyzed reaction (Fig. 11):

$$
\begin{aligned}
\mathrm{C}_{\mathrm{x}} \mathrm{H}_{2 \mathrm{y}} \mathrm{O}_{\mathrm{y}}+\mathrm{LiZnO} \rightarrow & {\left[\mathrm{C}_{\mathrm{x}} \mathrm{H}_{2 \mathrm{y}} \mathrm{O}_{\mathrm{y}} \cdot \mathrm{LiZnO}\right] * } \\
\rightarrow & \mathrm{LiZnO}+\mathrm{C}+\mathrm{CO}+\mathrm{CO}_{2}+\mathrm{H}_{2} \mathrm{O} \\
& +\mathrm{C}_{\mathrm{n}} \mathrm{H}_{2 \mathrm{n}}+\cdots
\end{aligned}
$$

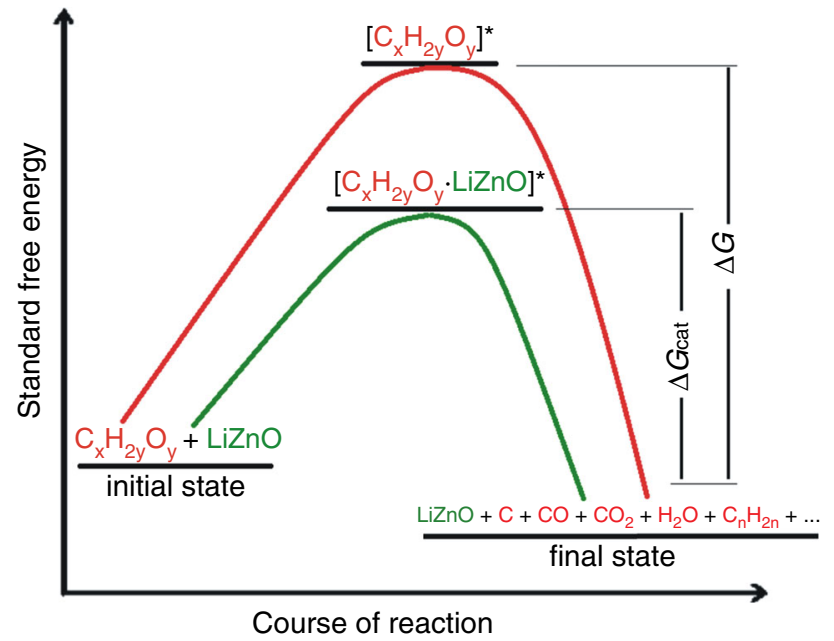

Fig. 11 Schematic diagram of the free energy profile and course of the $\mathrm{C}_{\mathrm{x}} \mathrm{H}_{2 \mathrm{y}} \mathrm{O}_{\mathrm{y}} / \mathrm{LiZnO}$ catalyzed reaction
Thermal processes during the sintering of the solid-state mixtures with rye grains and $\mathrm{LiZnO}$ particles result in the activation of the catalytic reaction in several ways:

- increase in catalyst surface area between the grain of rye and catalyst particles due to pore collapse,

- decrease in free energy of solid-state activation reaction that chemically transforms non-catalytic phase to active phase (activated complex),

- rapid decomposition of the active phase on the catalyst particles, carbon particles, methane, alkenes, and water molecules in a gaseous state

\section{Conclusions}

It was observed that a smaller amount of $\mathrm{Li}_{2 \mathrm{x}} \mathrm{Zn}_{1-\mathrm{x}} \mathrm{O}$ catalyst in relation to the grains produces a higher amount of carbonizate and lowers the grain decomposition temperature. Among the studied samples of $\mathrm{ZnO}, \mathrm{LiZnO}$, and $\mathrm{Li}_{2} \mathrm{ZnO}_{2}$ with the grain, $\mathrm{Li}_{2} \mathrm{ZnO}_{2}$ has the best catalytic properties to be used in the grains of cereals.

The $\mathrm{Li}_{2 \mathrm{x}} \mathrm{Zn}_{1-\mathrm{x}} \mathrm{O}$ systems serve as good catalysts in the decomposition of cereal grains. Resources of plant products (grains and their constituent polysaccharides) are practically inexhaustible. They constitute a major source of renewable energy. These renewable energy sources can and should play an important role in enhancing the profitability of agriculture and in the activation of the rural population. It is therefore necessary to build the global energy system for future generations and enlist the participation of a number of countries in these processes. Our results are compatible with the findings of previous research and observations forwarded by Poskrobko and Król, for example [25]. The interest in biofuels has resulted in the rapid development of research pertaining to the thermal decomposition and pyrolysis of dry biomass, such as cereal and oat straw and triticale, energy plants called sugar sorghum, and certain agricultural wastes [26]. The process of evaporation is similar to our observation for the $\mathrm{Li}_{2 \mathrm{x}}$ $\mathrm{Zn}_{1-\mathrm{x}} \mathrm{O}$ systems used for the decomposition of rye grains.

Acknowledgements Financial support from the National Science Centre, Poland (2015/19/N/ST8/03922 and 2014/15/B/ST8/00101), is gratefully acknowledged.

Open Access This article is distributed under the terms of the Creative Commons Attribution 4.0 International License (http://creative commons.org/licenses/by/4.0/), which permits unrestricted use, distribution, and reproduction in any medium, provided you give appropriate credit to the original author(s) and the source, provide a link to the Creative Commons license, and indicate if changes were made. 


\section{References}

1. Xie W, Yang Z, Chun H. Catalytic properties of lithium-doped $\mathrm{ZnO}$ catalysts used for biodiesel preparations. Ind Eng Chem Res. 2007;46:7942-9.

2. Du YL, Deng Y, Zhang MS. Investigation of Li-induced structural disorder and phase transition in $\mathrm{ZnO}$ by Raman spectroscopy. Solid State Comm. 2006;137:78-81.

3. Zhang JY, Jian LP, Hui S, Shen X, Deng TS, Zhu KT, Zhang QF, $\mathrm{Wu}$ JL. Ultraviolet electroluminescence from controlled arsenicdoped $\mathrm{ZnO}$ nanowire homojunctions. Appl Phys Lett. 2008;93:021116.

4. Shet S, Ahn KS, Yan Y, Deutsch T, Chrustowski KM, Turner J. Al-Jassim M, Ravindra NM. Carrier concentration tuning of bandgap-reduced pp-type $\mathrm{ZnO}$ films by codoping of $\mathrm{Cu}$ and $\mathrm{Ga}$ for improving photoelectrochemical response. J Appl Phys. 2008;103:073504-5.

5. Mandalapu LJ, Xiu FX, Yang Z, Zhao DT, Liu JL. $\rho$-type behavior from $\mathrm{Sb}$-doped $\mathrm{ZnO}$ heterojunction photodiodes. Appl Phys Lett. 2006;88:112108.

6. Fu ZW, Zhang LN, Qin QZ, Zhang YH, Zeng XK, Cheng H, Huang RB, Zheng LS. An experimental and ab initio study of hypervalent LiOZn. J Phys Chem A. 2000;104:2980-4.

7. Ganesh I, Sekhar PSC, Padmanabham G, Sundararajan G. Influence of Li-doping on structural characteristics and photocatalytic activity of $\mathrm{ZnO}$ nano-powder formed in a novel solution pyro-hydrolysis route. Appl Surf Sci. 2012;259:524-37.

8. Tang L, Wang B, Zhang Y, Gu Y. Structural and electrical properties of Li-doped p-type $\mathrm{ZnO}$ thin films fabricated by $\mathrm{RF}$ magnetron sputtering. Mat. Sci. Eng B. 2011;176:548-51.

9. Yousefi R, Zak AK, Jamali-Sheini F. The effect of group-I elements on the structural and optical properties of $\mathrm{ZnO}$ nanoparticles. Ceram Int. 2013;39:1371-7.

10. Pavlyuk V, Misztal R, Ciesielski W. Structural and thermal characterization of the incorporation of lithium into $\mathrm{ZnO}$. Eur. J. Inorg. Chem. 2014;925-31.

11. Mihaiu S, Szilágyi IM, Atkinson I, Mocioiu OC, Hunyadi D, Pandele-Cusu J, Toader A, Munteanu C, Boyadjiev S, Madarász J, Pokol G, Zaharescu M. Thermal study on the synthesis of the doped $\mathrm{ZnO}$ to be used in TCO films. J Therm Anal Calorim. 2016;124:71-80.

12. Ciesielski W, Kozioł JJ, Tomasik P. Complexes of amaranthus starch with selected metal salts and their thermolysis. Thermochim Acta. 2003;403:161-71.
13. Ciesielski W, Tomasik P. Coordination of cassava starch to metal ions and thermolysis of resulting complexes. Bull. Chem. Soc. Ethiopia. 2003;17:155-65.

14. Ciesielski W, Tomasik P. Complexes of amylose and amylopectins with multivalent metal salts. J Inorg Biochem. 2004;98:2039-51.

15. Ciesielski W, Tomasik P. Werner-type metal complexes of potato starch. Int J Food Sci Technol. 2004;39:691-8.

16. Ciesielski W, Lii CY, Yen MT, Tomasik P. Interactions of starch with salts of metals from the transition groups. Carbohydr Polym. 2003;51:47-56.

17. Lai VMF, Tomasik P, Yen MT, Hung WL, Lii CY. Re-examination of the interactions between starch and salts of metals from the non-transition groups. Int $\mathrm{J}$ Food Sci Technol. 2001;36:321-30.

18. Ciesielski W. Cereal grains as source for syngas. EJPAU. 2009;12:14.

19. Nozela WC, Braz CE. M, Almeida S. Ribeiro CA, Crespi MS. Mixture of biomass to energy reuse. J Therm Anal Calorim. 2018;131:765-69.

20. Boerrigter H. Greek diesel production with Fischer-Tropsch synthesis, http://www.senternovem.nl/mmfiles/26674_tcm23279868.pdf.

21. Pimentel D, Patzek TW. Ethanol production using corn, switchgrass, and wood; biodiesel production using soybean and sunflower. Nat Resour Res. 2005;14:65-76.

22. Schanke D, Hansen R, Sogge J, Hoftad KH, Wesenberg MH, Rytter E. Optimum integration of Fischer-Tropsch synthesis and syngas production. US Patent 6696501.

23. Srinivas S, Malik RK, Mahajani SM. Fisher-Tropsch synthesis using bio-syngas and $\mathrm{CO}_{2}$, Advances in Energy Research (AER2006): Proceedings of the 1st National Conference on Advances in Energy Research, Department of Energy Systems Engineering. Indian Institute of Technology, Bombay: 2016,317.

24. Zwart R. Large scale Fischer-Tropsch diesel production, http:// tu-freiberg.de/sites/default/files/media/professur-fuer-energie verfahrenstechnik-und-thermische-rueckstandsbehandlung16460/publikationen/2007-7-1.pdf.

25. Poskrobko S, Biofuels Król D, Part II. Thermogravimetric research of dry decomposition. J Therm Anal Calorim. 2012;109:629-38.

26. Lupascu T, Dranca I, Popa VT, Vass M. Application of Thermal Analysis to the Study of Some Waste Agricultural Products for the Preparation of Active Carbons. J Therm Anal Calorim. 2001;63:855-63. 